\title{
Prolactin Receptor Is Associated with c-src Kinase in Rat Liver
}

\author{
Juan Jose Berlanga*, Juan Angel Fresno Varat, \\ Jorge Martín-Pérez, and Josefa P. García-Ruiz \\ Departamento de Biologia Molecular (J.J.B., J.P.G.-R.) \\ Centro de Biologia Molecular Severo Ochoa \\ Campus Cantoblanco \\ 28049 Madrid, Spain \\ Instituto de Investigaciones Biomédicas C.S.I.C. (J.A.F.V., J.M.P.) \\ Arturo Dupezier 4 \\ 28029 Madrid, Spain
}

\begin{abstract}
The mechanism of action of the pituitary hormone PRL was studied in hepatocytes of lactating rats. PRL receptor immune complexes obtained from llver lysates have an associated tyrosine kinase activity. The tyrosine kinase has been identified in isolated hepatocytes as $\mathrm{pp60} \mathrm{0}^{\mathrm{c}-\mathrm{src}}$. Incubation of hepatocytes with PRL induces the association of PRL receptor with pp60 ${ }^{\mathrm{c}-\mathrm{src}}$ and the resultant stimulation of its tyrosine kinase activity. Furthermore, PRL stimulates the gene expression of c-fos, c-jun, and $c$-src. All of these findings support the idea that the pp60 ${ }^{\mathrm{c}-\mathrm{src}}$ tyrosine kinase participates in the early steps of the PRL intracellular signaling that promotes cell growth in liver cells. (Molecular Endocrinology 9: 1461-1467, 1995)
\end{abstract}

\section{INTRODUCTION}

In vertebrates, the pituitary hormone PRL has been involved in many functions, including reproduction, lactation, growth, differentiation, and immune response. In accordance with PRL pleiotropic functions, PRL receptors (PRLR) are widely distributed in mammalian tissues. PRLR belong to the genetically defined cytokine/hematopoietin receptor family, which includes $\mathrm{GH}$ and a number of cytokines [interleukins 2-7 (IL-2 to IL-7), granulocyte/macrophage colony-stimulating factor, granulocyte colony-stimulating factor, and erytropoietin] receptors (1). The members of this large family share common structural elements in their extracellular domain, including four paired cysteine residues and a highly conserved WSXWS motif. Although intracellular domains differ markedly in size and have low sequence homology, a hydrophobic proline-rich segment in the membrane proximal region is highly conserved. This region of homology (box 1) has been shown to be essential for signal transduction in all cases studied (2-7). Although none of these recep-

0888-8809/95/\$3.00/0

Molecular Endocrinology

Copyright $(0) 1995$ by The Endocrine Society tors contains any obvious enzymatic activity, it has been shown that they associate with and activate specific tyrosine kinases (8). To date, the Jak and Src tyrosine kinase families have been widely involved with the cytokine/hematopoietin receptors. Jak2 has been shown to participate in the signaling of many receptors, such as the GH receptor in $3 \mathrm{~T} 3$ fibroblasts (5) or the erytropoietin receptors and the IL-3 receptors in DA3 myeloid cells $(9,10)$. Jak3 is coupled to the IL-2 receptor in lymphoid and myeloid cells $(11,12)$, and Jak1, Jak2 and Tyk2 are implicated in the signaling mechanisms of interferons $(13,14)$. The Src family tyrosine kinases Lck, Lyn, and Fyn, on the other hand, are activated by IL-2, IL-3, and IL-7, respectively (1517). Thus far, the exact role of these protein tyrosine kinases is not fully understood.

In mammalian cells, two forms of PRLR have been identified and cloned. They are generated by differential splicing of a single gene and differ only in the length of their intracellular domain (1). In addition, a fully functional mutant of the long form that lacks 198 amino acids in its cytoplasmic region has been shown to be predominant in the PRL-dependent Nb-2 11C cell line (18). In this pre-T rat lymphoma cell line, PRLR constitutively associates with Jak2 $(19,20)$, p59 fyn (21), and RAF-1 serine-threonine kinase (22), respectively. In BAF-3 cells transfected with the long form of the PRLR, the receptor also associates with Jak2 (23). In all of these cases, binding of ligand to the PRL receptor activates preassociated kinases. In addition, PRL stimulation triggers the tyrosine phosphorylation of both the kinase and the receptor $(20,23,24)$. Jak family activation has been related to the regulation of gene expression through tyrosine phosphorylation of signal transducers and activators of transcription (Stat) transcriptional factors (25). However, the role of PRLR tyrosine phosphorylation is unknown.

To examine the biological function of the PRLR isoforms, Chinese hamster ovary cell lines expressing each form were cotransfected with constructions carrying milk protein promoters. It was thus demonstrated that the long and Nb-2 forms of PRLR are able 
to induce $\beta$-lactoglobulin and $\beta$-casein promoters (26). In addition, both PRLR isoforms mediate the PRL induction of interferon regulatory factor-1 promoter and cellular proliferation in the IL-3-dependent cell lines (27). However, the function of the short form of the PRLR remains to be established.

The liver is one of the main targets for PRL according to the level of PRLR transcripts, and it is the only tissue in which the short form of the receptor is predominant (28). We previously reported that PRL increases both c-myc gene expression (29) and the cytosolic free calcium concentration (30) in isolated hepatocytes. In this work we analyzed the PRL signal transduction pathway in isolated hepatocytes of lactating rats. We demonstrate that PRL stimulation of cells induces the association of PRLR with pp60 ${ }^{c-s r c}$, pp60 $0^{\text {-src }}$ activation and an increase in c-fos, c-jun, and c-src gene expression.

\section{RESULTS}

\section{Kinase Activity in PRLR Immune Complexes}

We first studied whether the PRLR was associated with a kinase activity that could account for the intracellular signaling of PRL in the liver of lactating rats. For this purpose, PRLR was immunoprecipitated with monoclonal antibody (MAb) T6 from a detergent-solubilized liver extract and assayed for in vitro kinase activity (see Materials and Methods). An example of these experiments is shown in Fig. 1, lane 1. We consistently detected two phosphorylated proteins, the immunoglobulin $\mathrm{G}(\mathrm{lgG})$ heavy chain and a protein of approximately 60 kilodaltons (p60). As some members of the cytokine receptor family associate with protein kinases of the Src family $(15,17,21,31-34)$, an aliquot of the liver extracts was used to immunoprecipitate c-src with MAb 327 and assayed for autophosphorylation (see Materials and Methods). As indicated in Fig. 1 , lane 2, the electrophoretic resolution of the c-srcMAb 327 immune complex showed three phosphorylated bands corresponding to an autophosphorylated (pp60 ${ }^{\mathrm{c}-\mathrm{src}}$ band) product, the $\mathrm{lgG}$, and another unidentified (p45) protein. Interestingly, the p60 detected in PRLR immune complexes comigrated with pp60 6 -src. Moreover, the ${ }^{32} \mathrm{P}$ incorporated into these proteins was resistant to $\mathrm{KOH}$ treatment (data not shown), which means that they were phosphorylated in tyrosine residues. These initial results led us to conclude that a protein tyrosine kinase is associated with PRLR in the liver of lactating rats.

\section{PRLR Association with pp60 6 -src}

Isolated hepatocytes from lactating rats were used to demonstrate a plausible physical association of PRLR with $\mathrm{pp} 60^{\mathrm{c}-\mathrm{src}}$ and to analyze the possible role of PRL in such an interaction. We determined whether C-src was coprecipitated with PRLR immune complexes. A

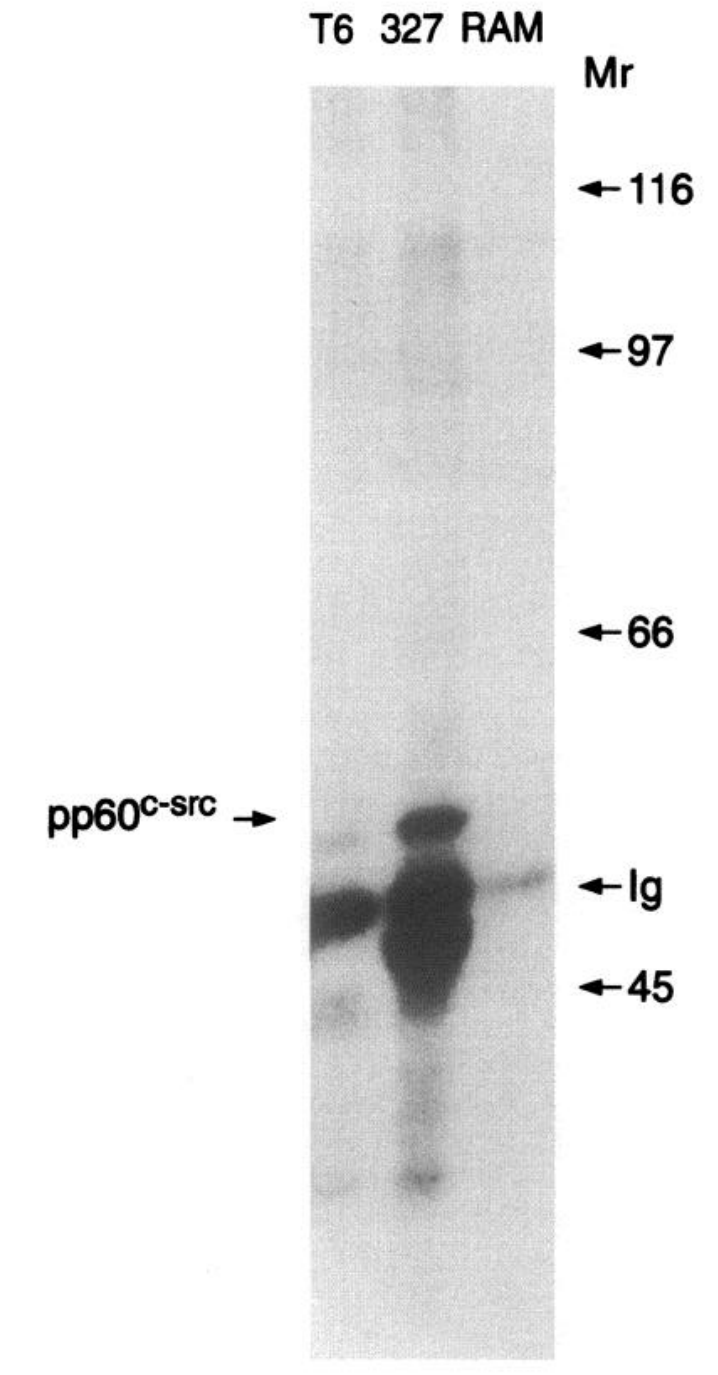

Fig. 1. PRLR Immune Complex Kinase Assay

Proteins from liver of lactating rats were solubilized as described in Materials and Methods. Aliquots derived from $1 \mathrm{~g}$ tissue were used to immunoprecipitate PRLR with T6 (lane 1) and pp60 $60^{\mathrm{c}-\mathrm{src}}$ with 327 (lane 2). A rabbit antimouse serum was used as a control (lane 3). The immune complexes were subjected to in vitro kinase reaction for $10 \mathrm{~min}$ at room temperature and resolved in a 7\% SDS-polyacrylamide electrophoresis gel. The phosphoproteins were detected by autoradiography. Standard proteins and migration of $\mathrm{pp} 6 \mathrm{O}^{\mathrm{c}-\mathrm{src}}$ are indicated.

representative assay (one of four experiments) is shown in Fig. 2. Four aliquots of $6 \times 10^{7}$ cells were incubated for $30 \mathrm{~min}$ in the presence or absence of ovine PRL (oPRL; $1 \mu \mathrm{g} / \mathrm{ml}$ ). The cell lysates were used to immunoprecipitate PRLR with MAb U5 (lanes 3 and 4) or pp60 ${ }^{\mathrm{c}-\text { src }}$ with MAb LA074 (lane 2). A mouse preimmune serum (prel) was used as a control (lane 1). The immune complexes were electrophoretically resolved in a sodium dodecyl sulfate (SDS)-10\% polyacrylamide gel, transferred to a nitrocellulose membrane, and probed with anti-pp60 ${ }^{c-s r c}$ MAb LA074. In the absence of hormone, c-src kinase was minimally associated with PRLR (lane 3). However, after a 30- 


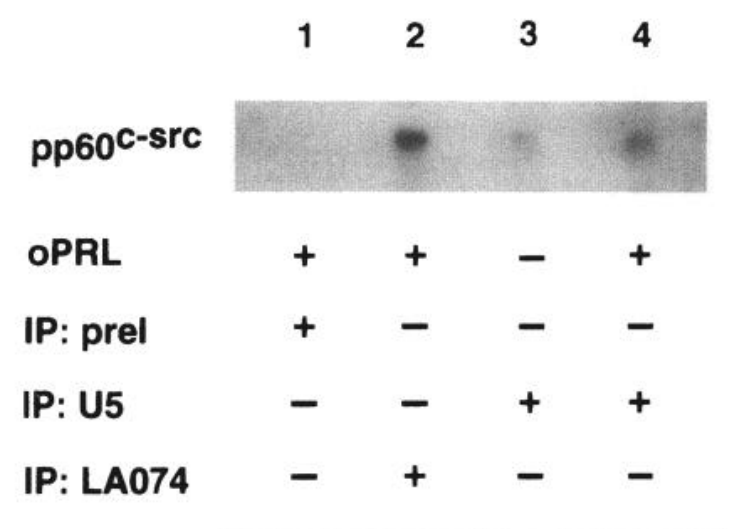

BLOT: LA074

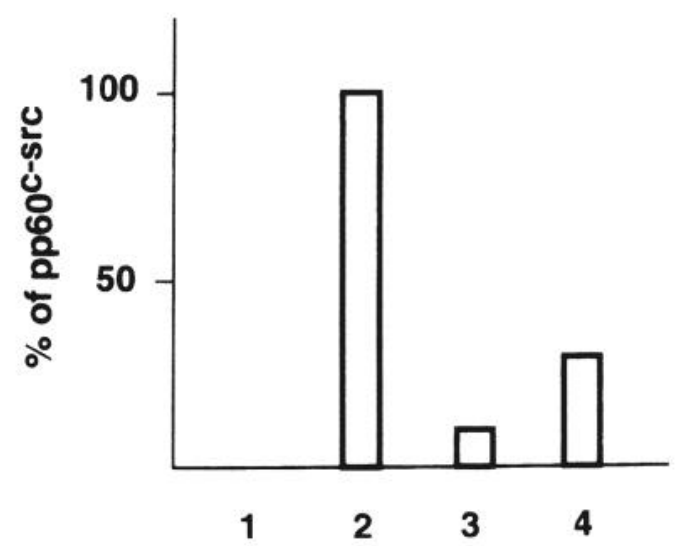

Fig. 2. Association of $p p 60^{c-s r c}$ with the PRLR

Samples containing $6 \times 10^{7}$ hepatocytes isolated from lactating rats were preincubated for $30 \mathrm{~min}$ in the absence of hormone and then incubated for $30 \mathrm{~min}$ more with or without oPRL ( $1 \mu \mathrm{g} / \mathrm{ml})$. The lysates were used to immunoprecipitate PRLR with U5 (lanes 3 and 4) and pp60 ${ }^{\mathrm{c}-\text { src }}$ with 327 (lane 2), and preimmune mouse serum was used as a control (lane 1). The immune complexes were dissociated in nonreducing loading buffer, resolved in SDS-10\% PAGE, blotted onto nitrocellulose, and probed for $\mathrm{pp} 60^{\mathrm{c}-\mathrm{src}}$ with LA074. Detection was carried out by incubation with [ $\left.{ }^{125} \mid\right]$ sheep antimouse IgG and autoradiography (see Materials and Methods). The lower panel shows the densitometric analysis of four different experiments. They are expressed as a percentage of the value obtained with pp $60^{\text {c-src }}$. SEMS were \pm 3.7 and \pm 7.6 for the data in lanes 3 and 4 , respectively.

min stimulation with PRL, a significant amount of C-src coprecipitates with PRLR (lane 4), whereas no c-src can be detected in control immunoprecipitates (lane 1). Densitometric analysis of the blots from four different experiments demonstrated that addition of ligand resulted in a 3-fold increase in the amount of $\mathrm{pp} 60^{\mathrm{c}-\mathrm{src}}$ coupled to the receptor in liver cells.

Two different approaches were used to demonstrate that PRL stimulates the tyrosine kinase activity of pp60 6 -src. As the increase in c-src kinase activity correlates with an increase in autophosphorylation (35-37), we first tested whether pp60 $0^{\mathrm{c}-\mathrm{src}}$ was tyrosine phosphorylated in response to PRL. Hepatocytes isolated from lactating rats (aliquots of $6 \times 10^{6}$ cells) were treated for $10 \mathrm{~min}$ with different amounts of PRL, and pp60 ${ }^{\text {c-src }}$ was immunoprecipitated from the corresponding cell lysates. The content of phosphotyrosine in $\mathrm{pp} 60^{\mathrm{c}-\mathrm{src}}$ was detected by Western blot probing with PY20 antibody. Figure 3 shows that in this system, pp $60^{\mathrm{c}-\text { src }}$ is tyrosine phosphorylated in a PRL amount-dependent manner. Densitometric analysis showed that PRL present at a concentration of 0.05 $\mu \mathrm{g} / \mathrm{ml}$ increased the phosphotyrosine content of c-src by 2 -fold, and $1 \mu \mathrm{g} / \mathrm{ml} \mathrm{PRL}$ increased the phosphotyrosine content by 3.7 -fold.

In a second approach, we performed a timecourse stimulation of isolated hepatocytes with PRL and tested the kinase activity of $\mathrm{pp} 60^{\mathrm{c}-\mathrm{src}}$ using acid-denatured enolase as an exogenous substrate. As shown in Fig. 4, the activity of pp60 $60^{\text {-src }}$ in response to PRL addition followed a transient stimulation pattern, peaking at $2-10 \mathrm{~min}$ and returning to basal levels within $20 \mathrm{~min}$. PRL increased by 1.8 -fold the total cellular c-src kinase activity within $10 \mathrm{~min}$ after stimulation.
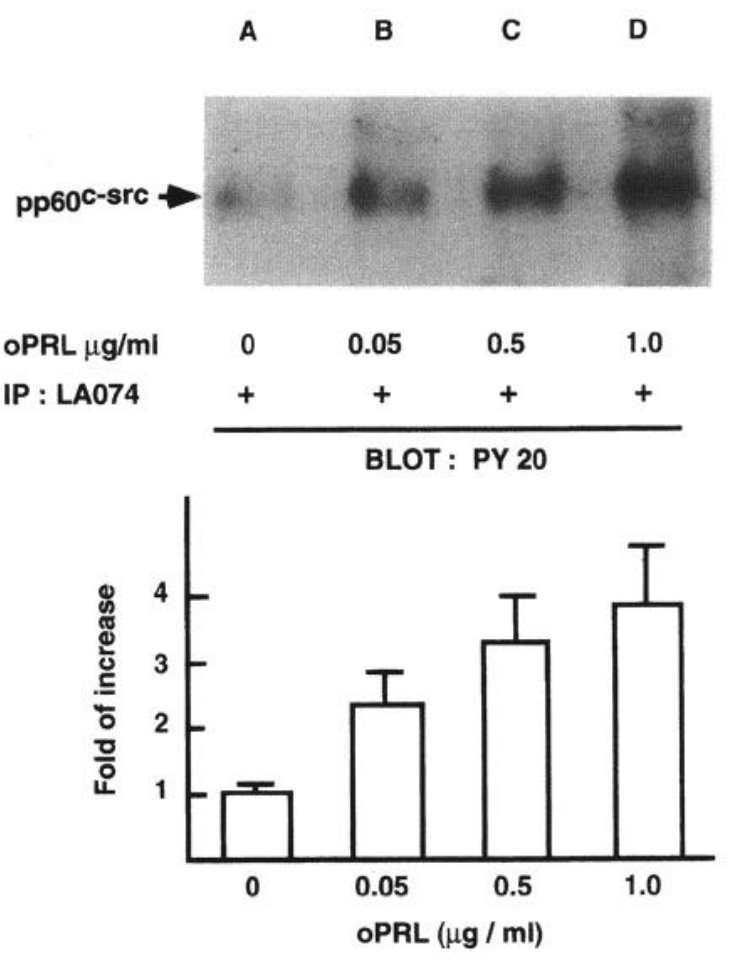

Fig. 3. PRL Induction of $p p 60^{c-s r c}$ Tyrosine Phosphorylation Hepatocytes $\left(6 \times 10^{6}\right)$ from lactating rats were incubated with different concentrations of oPRL for $10 \mathrm{~min}$. Then, $\mathrm{pp} 60^{\mathrm{c}-\mathrm{src}}$ was immunoprecipitated from the cell lysates, and the immune complexes were dissociated in nonreducing loading buffer, resolved in SDS-9\% PAGE, blotted, probed with the antiphosphotyrosine antibody PY20, and developed with ECL (see Materials and Methods). The lower panel shows the densitometric analysis of three different experiments. Phosphorylation results were normalized for the amount of $\mathrm{pp}^{\mathrm{c}} \mathrm{O}^{\mathrm{s}-\mathrm{src}}$ detected by reprobing the blot with LA074, and error bars indicate the SEM. 


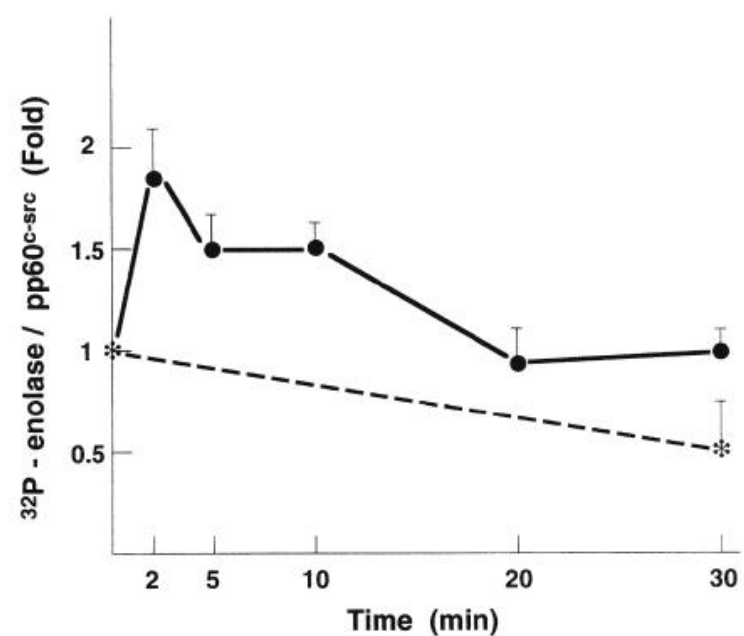

Fig. 4. PRL Induction of pp60 $60^{\mathrm{c}-\mathrm{src}}$ Kinase Activity

Hepatocytes $\left(6 \times 10^{6}\right)$ isolated from lactating rats were incubated with (0) or without ( $\left.{ }^{*}\right)$ OPRL $(1 \mu \mathrm{g} / \mathrm{ml})$ for 0-30 min. pp60 $60^{\text {-src }}$ was immunoprecipitated from cell lysates with $\mathrm{LA074}$, and the in vitro kinase activity was measured within 3 min using acid-denatured enolase as exogenous substrate in the presence of $\left[\gamma-{ }^{32}\right.$ P]ATP. The reaction were stopped by the addition of nonreducing loading buffer, resolved in SDS-9\% PAGE, and blotted onto nitrocellulose. Filters were subjected to autoradiography and finally probed with LA074 (see Materials and Methods). The phosphorylation results were normalized for the amount of pp60 $0^{\mathrm{csrc}}$ detected in Western blot and expressed as fold induction with respect to zero time. They are the mean of five separate experiments, and error bars indicate the SEM.

These data are in good agreement with the activation of c-src kinase by colony stimulating factor- 1 (32). Thus, the results suggest that $P R L$ signal transduction in liver cells is mediated at least in part by PRLR association with $\mathrm{pp} 60^{\mathrm{c}-\mathrm{src}}$ and the stimulation of its tyrosine kinase activity.

\section{PRL Increases the c-fos, c-jun, and c-src Levels of mRNA in Hepatocytes}

The changes in cell growth rate and phenotype elicited by growth factors are believed to be initiated by the transcriptional induction of a set of immediate early response genes (38-40). Our previous studies have shown that oPRL stimulates expression of the protooncogene c-myc (29). We assessed the possible effect of PRL on the expression of c-fos, c-jun, and c-src in isolated hepatocytes. As shown in Fig. 5 , this hormone significantly increases the levels of mRNA for the protooncogenes c-fos (9-fold), c-jun (13-fold), and c-src (3.6-fold). In the absence of protein synthesis, the levels of the above-mentioned genes were increased by factors of $3.1,7.2$, and 3.4, respectively. These data suggest that PRL is involved in the regulation of these important immediate early response genes.
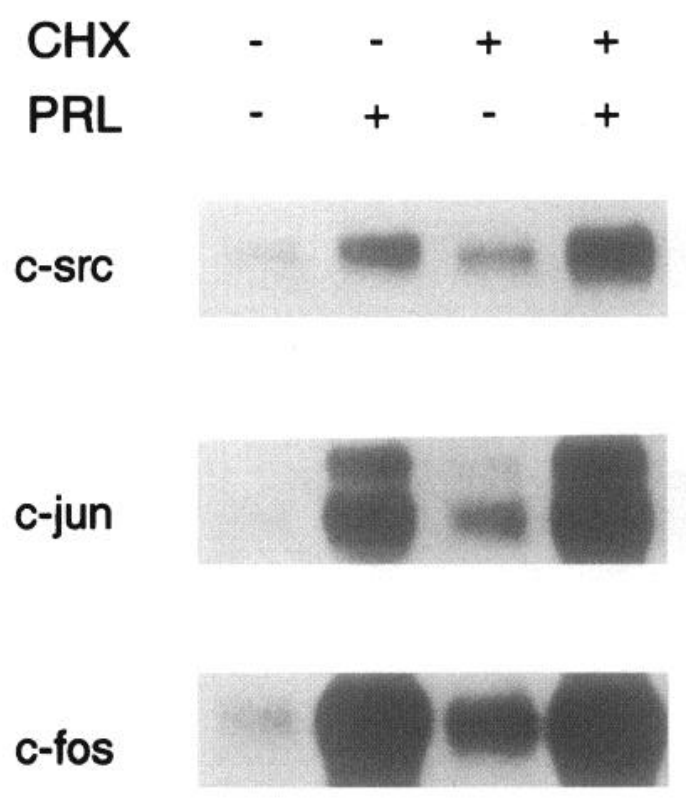

\section{$\beta$-Act}

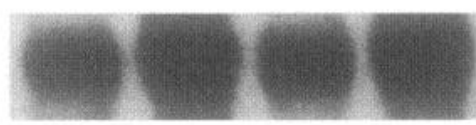

Fig. 5. PRL Activation of Immediate Early Response Genes and C-src in Isolated Hepatocytes

Hepatocytes isolated from lactating rats were incubated at $5 \times 10^{7}$ cells $/ 50 \mathrm{ml}$ incubation medium. After $30 \mathrm{~min}$ of preincubation, cells were incubated with $1 \mu \mathrm{g} / \mathrm{ml}$ oPRL in the presence or absence of $10 \mu \mathrm{g} / \mathrm{ml}$ cycloheximide for $2 \mathrm{~h}$. Polyadenylated RNA $(5 \mu \mathrm{g})$ was analyzed by Northern blotting for c-fos, c-jun, c-src, and $\beta$-actin mRNAs.

\section{DISCUSSION}

It is now well established that cytokines initiate the intracellular signaling pathways by activation of multiple protein tyrosine kinases associated with their receptors (see Ref. 41 for review). The identification of protein tyrosine kinases associated with each receptor is the first step in understanding the biological role of these kinases. In the work presented here we demonstrated that the protein tyrosine kinase $\mathrm{pp} 60^{\mathrm{c} \text {-src }}$ associates with PRLR in liver cells upon PRL stimulation. Another member of the Src family kinases, p56 fyn , has been identified as being permanently associated with PRLR isoforms expressed in Nb-2 cells (21). Although pp60 ${ }^{\mathrm{c}-\mathrm{src}}$ was detected in PRLR immune complexes, we were unable to detect PRLR in Western analysis of PRLR or pp $60^{\mathrm{c}-\text { src }}$ immunoprecipitates. A potential explanation for this apparent discrepancy could be that anti-PRLR antibodies (U5 and U6 were used) have a lower affinity for the denatured receptor than for the native form.

In this work we show that PRL promotes both pp60 $0^{\mathrm{c}-\mathrm{src}}$ association with PRLR and activation of this protein tyrosine kinase. As reviewed by Erpel and 
Courtneidge (42), activation of Src family kinases could occur in three ways: dephosphorylation of phosphotyrosine 527 at the carboxy-terminal region, competition for the SH2 domain by a high affinity phosphotyrosine-containing ligand, and competition for the $\mathrm{SH} 3$ domain by a high affinity proline-rich ligand. The PRLR isoforms have a PPVP motif at the membraneproximal region that may be involved in the coupling of Jak or Src family kinases. However, activation of the members of the latter family by interaction with the $\mathrm{SH} 3$ domain has not yet been reported. The activation of Src by a phosphotyrosine-containing ligand has been demonstrated during ligand activation of platelet-derived growth factor receptor (43). As Jak2 is constitutively associated with PRLR isoforms in Nb-2 $(19,20)$, BAF-3 $(23)$, mammary gland $(44,45)$, and 293 cells (46), it is possible that a Jak family member or another protein tyrosine kinase expressed in liver cells mediates a initial tyrosine phosphorylation of PRLR upon PRL stimulation. After the initial tyrosine phosphorylation of PRLR or PRLR-protein tyrosine kinase complex, the activation of $\mathrm{pp} 60^{\mathrm{c}-\mathrm{src}}$ must occur by competition for the $\mathrm{SH} 2$ domain. In agreement with this explanation, recently published data have demonstrated that a proline-rich sequence is required for Jak2 association with the PRLR, but is not sufficient for signal transduction (24). In addition, a single phosphotyrosine residue located at the carboxy-terminal region of the PRLR is responsible for PRL-dependent induction of $\beta$-casein promoter in 293 cells (46). Interestingly, PRL stimulates tyrosine phosphorylation of different tyrosine residues of PRLR isoforms, but the mutation of the distal tyrosine prevents the receptor from inducing the $\beta$-casein promoter. The transducer molecule binding the distal phosphotyrosine of PRLR and involved in the activation of milk protein gene transcription has not yet been identified.

In hepatocytes, we have also shown that PRL stimulates expression of the protooncogenes c-fos, $c-j u n$, and $c$-src. This suggests that PRL stimulates the expression of genes with AP-1 or SRE sequences in their promoter regions. However, the possible substrates or kinases downstream of pp60 ${ }^{\mathrm{c}-\mathrm{src}}$ in liver cells to drive PRL messenger to the nucleus need to be established. Src kinases are involved in Ras activation in fibroblasts (47), phosphorylation of cytoskeletal proteins $(48,49), \mathrm{c}-m y c$ induction (50), or Sam68 phosphorylation (51) among other functions (see Ref. 42 for review). As Raf is activated by PRL (22), it is interesting to speculate that Ras activation may be involved in PRL intracellular signaling in hepatocytes. However, a Src-Ras-independent pathway has been demonstrated in IL-2, granulocyte-macrophage colony-stimulating factor, and epidermal growth factor receptor signaling $(52,53)$. Which of these two mechanisms controls the expression of PRL-induced expression of c-myc in liver cells needs to be determined (29). We hope that future work will clarify our understanding of the interaction among PRLR with pp60 ${ }^{\mathrm{c}-\mathrm{src}}$, the mechanism of $\mathrm{pp} 6 \mathrm{O}^{\mathrm{c}-\mathrm{src}}$ activation, and the role of this kinase in liver cells.

\section{MATERIALS AND METHODS}

\section{Preparation and Culturing of Rat Hepatocytes}

Hepatocytes were isolated from lactating Wistar rats, which were maintained on a 12-h light, 12-h dark photoperiod, 2-3 days after delivery. The livers were perfused for $20 \mathrm{~min}$ with Krebs-Henseleit (calcium-free) buffer containing $40 \mathrm{mg} / \mathrm{ml}$ collagenase (Boehringer Mannheim, Indianapolis, IN) and supplemented with $5 \mathrm{~mm}$ glucose, $2 \mathrm{~mm}$ glutamine, $100 \mathrm{U} / \mathrm{ml}$ penicillin, and $1 \%$ BSA (54). Cells were washed and incubated as described previously (29). Cell viability, determined by the trypan blue exclusion test, was approximately $90 \%$. The PRL used (oPRL) was kindly provided by the NIDDK (National Hormone and Pituitary Program).

\section{Antisera and Immunoprecipitations}

Isolated hepatocytes were lysed at a concentration of $25 \times$ $10^{6}$ cells $/ \mathrm{ml}$ in $25 \mathrm{~mm}$ Tris- $\mathrm{HCl}$ (pH 7.4), $4 \mathrm{~mm}$ EDTA, $50 \mathrm{~mm}$ sodium fluoride, $10 \mathrm{~mm}$ sodium pyrophosphate, $2 \mathrm{~mm}$ sodium orthovanadate, $1 \mathrm{~mm}$ phenylmethylsulfonylfluoride, 0.3 $\mathrm{mg} / \mathrm{ml}$ bacitracin, $0.3 \mathrm{mg} / \mathrm{ml}$ trypsin inhibitor, $1 \mathrm{mg} / \mathrm{ml}$ benzamidine, and $2 \%$ Triton $X-100$ for 30 min at $4 \mathrm{C}$. When entire livers were used, they were rinsed once with ice-cold PBS and homogenized at $4 \mathrm{C}$ in lysis (Triton-free) buffer ( $1 \mathrm{~g}$ liver $/ 5$ ml) with a Polytron (Brinkmann Instruments, Westbury, NY) three times for 30 sec each time and then adjusted to $2 \%$ Triton $\mathrm{X}-100$. After $30 \mathrm{~min}$ of continuous rotation at $4 \mathrm{C}$, insoluble material was removed by centrifugation at $25,000 \times$ $g$ for $45 \mathrm{~min}$ at $4 \mathrm{C}$. The resulting supernatants were diluted (1:1) with buffer A [20 mM Tris- $\mathrm{HCl}(\mathrm{pH} 7.4), 140 \mathrm{~mm} \mathrm{NaCl}, 5$ mM EDTA, and $1 \%$ Triton $X-100]$ before immunoprecipitation. The antibodies used in the experiments were U5, U6, or T6 anti-rat PRLR recognizing the extracellular domain of PRLR [characterized by Okamura et al. (55)] at $2 \mu \mathrm{g} / \mathrm{ml} ; 327$ antipp60 ${ }^{\text {c-src }}$ (generously provided by Dr. J. S. Brugge) at $5 \mu$ l ascites/ml; LA074 anti-pp60c-src (Quality Biothech, Camden, $\mathrm{NJ}$ ) at $5 \mu \mathrm{l}$ ascites/ml; and PY20 antiphosphotyrosine (ICN, Costa Mesa, CA) at $2 \mu \mathrm{g} / \mathrm{ml}$. Immunoprecipitations were performed for $2 \mathrm{~h}$ at $4 \mathrm{C}$. Immune complexes were precipitated with rabbit antimouse IgG (RAM) (Nordic Immunological Laboratories, Tilburg, The Netherlands) bound to protein ASepharose and washed as follows: three times with buffer B [10 mM Tris- $\mathrm{HCl}$ (pH 7.4), $5 \mathrm{~mm}$ EDTA, $50 \mathrm{~mm} \mathrm{NaCl}, 30 \mathrm{~mm}$ sodium pyrophosphate, $50 \mathrm{~mm} \mathrm{NaF}, 100 \mu \mathrm{M} \mathrm{Na} \mathrm{VO}_{4}, 1 \%$ Triton $X-100,1 \mathrm{~mm}$ phenylmethylsulfonylfluoride, $2 \mu \mathrm{g} / \mathrm{ml}$ leupeptin, and $0.5 \mathrm{mg} / \mathrm{ml}$ benzamidine], once with $0.5 \mathrm{M} \mathrm{LiCl}$, and, finally, twice with $10 \mathrm{~mm}$ Tris- $\mathrm{HCl}(\mathrm{pH} 7.4), 1 \mathrm{~mm}$ EDTA, and $100 \mathrm{~mm} \mathrm{NaCl}$.

\section{In Vitro Kinase Reactions}

The clean immune complexes were washed once more with kinase buffer $\left[30 \mathrm{~mm}\right.$ Tris- $\mathrm{HCl}(\mathrm{pH} 7.4)$ and $\left.5 \mathrm{~mm} \mathrm{MnCl} \mathrm{Mn}_{2}\right]$ and incubated at room temperature in $20 \mu \mathrm{l}$ kinase buffer containing $10 \mu \mathrm{Ci}\left[\gamma^{32}{ }^{32}\right.$ PATP $(3000 \mathrm{Ci} / \mathrm{mmol})$ and $5 \mu \mathrm{g}$ aciddenatured enolase for dlfferent time intervals. These reactions were stopped at different times by the addition of $20 \mu \mathrm{l}$ twice concentrated SDS-gel loading buffer and boiled for 10 min. Depending on the experiment, a nonreducing loading buffer $(125 \mathrm{~mm}$ Tris- $\mathrm{HCl}, \mathrm{pH} 6.8$, containing $4 \%$ SDS, $20 \%$ glycerol, and $18.5 \mathrm{mg} / \mathrm{ml}$ iodoacetamide) was alternatively used. Samples were analyzed by SDS-polyacrylamide gel electrophoresis (SDS-PAGE). Gels were dried or transferred to nitrocellulose (Schleicher and Schuell, Dassel, Germany) and exposed to Kodak X-Omat AR films (Eastman Kodak, Rochester, NY). The autoradiograms were scanned using a Molecular Dynamic scanner (Sunnyvale, CA) or a PhosphorImager from Bio-Rad (Richmond, CA). 


\section{Immunoblotting}

The association of PRLR with pp60 $60^{\mathrm{c}-\mathrm{src}}$ in hepatocytes was demonstrated as follows. Aliquots of $6 \times 10^{7}$ cells were incubated with or without oPRL $(1 \mu \mathrm{g} / \mathrm{ml})$ for $30 \mathrm{~min}$ at room temperature, pelleted, and disrupted in $3 \mathrm{ml}$ lysis buffer as before. Immunoprecipitations were carried out using mouse nreimmune serum (as a controll antj-PRI R IMAh J I5l or

washed three times with buffer $B$ and heated at $80 \mathrm{C}$ for $3 \mathrm{~min}$ in $125 \mathrm{~mm}$ Tris- $\mathrm{HCl}$, pH 6.8, containing 4\% SDS, $20 \%$ glycerol, and $18.5 \mathrm{mg} / \mathrm{ml}$ iodoacetamide. The proteins were resolved by SDS-PAGE and transferred to nitrocellulose. The nitrocellulose membrane was blocked at $37 \mathrm{C}$ for $2.5 \mathrm{~h}$ with Tris-buffered saline containing 5\% milk proteins (Fluka BioChemica, Buchs, Switzerland) and 0.05\% Tween 20 (TTBS). The blotted proteins were probed for $1 \mathrm{~h}$ at room temperature with MAb LAO74 diluted 1:125 in TTBS containing $5 \%$ milk protein, then incubated with ${ }^{125} \mathrm{I}$-labeled sheep antimouse IgG $(0.5 \mu \mathrm{Ci} / \mathrm{ml}$; Amersham Corp., Arlington Heights, IL), washed, and exposed to film. Alternatively, nitrocellulose membranes were blocked with either $5 \%$ nonfat BSA or $5 \%$ milk protein for $3 \mathrm{~h}$ and incubated overnight at $4 \mathrm{C}$ with $P Y 20$ antibody diluted 1:1000 in TTBS containing 1\% BSA or with LAO74 diluted 1:125 in TTBS containing $5 \%$ milk protein. The secondary antibody used for detection was labeled with antimouse horseradish peroxidase. The blots were washed and developed using the ECL chemiluminiscence system (Amersham Corp.) according to the manufacturer's instructions.

\section{Isolation and Quantitation of mRNA}

Total RNA was isolated from lactating rat hepatocytes using the standard phenol protocol and enriched for polyadenylated RNA by a single passage through an oligo(deoxythymidine)-cellulose column (56). The RNA was fractionated and transferred to Hybond-N nylon membranes as previously described (29). Gelpurified DNA probes were either a 2.6-kb Pstl insert of mouse $\mathrm{c}$-jun-coding sequence (38) or a 1.2-kb Pstl insert of mouse $c$-fos-coding sequence, kindly provided by Dr. Naranjo (Instituto Cajal, Madrid, Spain). The probes for c-src and $\beta$-actin were purchased from Clontech (Palo Alto, CA). They were labeled by nick translation with $\left[\alpha_{-}{ }^{32} \mathrm{P}\right]$ deoxy-CTP to a specific activity of $1-2 \times 10^{8} \mathrm{cpm} / \mu \mathrm{g}$ (57). The hybridization results were expressed as the ratio to $\beta$-actin messenger.

\section{Acknowledgments}

We especially thank Dr. P. A. Kelly for providing PRLR antibodies, Mr. Javier Palacin and Mr. Juan M. Sparrowe for their skillful assistance with the animals, Mr. Javier Pérez Garcia and Mr. Antonio Fernández González for the art design and photography, and Dr. I. Sandoval for the critical review of the manuscript.

Received June 2, 1995. Re-revision received July 27, 1995. Accepted August 1, 1995.

Address requests for reprints to: Dr. P. Garcia-Ruiz, Department de Biologia Molecular, Centro de Biologia Molecular Severo Ochoa, Campus Cantoblanco, 28049 Madrid, Spain.

This work was supported by grants from the DGICYT (PM91-0223 and PB93-0136), CAM (C137/91 and C263/ 91A), and the Ramón Areces Foundation.

* Supported by the Ph.D. fellowship program from the Ministerio de Educación y Ciencia.

† Supported by the Ph.D. fellowship program from the Vasque Government.

\section{REFERENCES}

1. Kelly PA, Djiane J, Postel-Vinay MC, Edery M 1991 The prolactin/growth hormone receptor family. Endocr Rev 12:235-251

2. Murakami M, Narazaki M, Hibi M, Yawata $H$, Yasukawa K, Hamaguchi M, Taga T, Kishimoto T 1991 Critical cy-

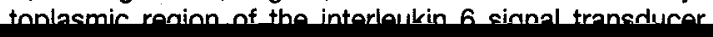

Natl Acad Sci USA 88:11345-11353

3. Fukunaga R, Ishizada-Ikeda E, Pan CX, Seto Y, Nagata S 1991 Functional domains of the granulocyte colony-stimulating factor receptor. EMBO J 10:2855-2865

4. Sakamaki K, Miyajima I, Kitamura T, Miyajima A 1992 Critical cytoplasmic domains of the common \& subunit of the human GM-CSF, IL-3 and IL-5 receptors for growth signal transduction and tyrosine phosphorylation. EMBO J 11:3541-3549

5. Argentsinger LS, Campbell GS, Yang $X$, Witthuhn $B$, Silvennoinen O, Ihle JN, Carter-Su C 1993 Identification of JAK2 as a growth hormone receptor-associated tyrosine kinase. Cell $74: 237-244$

6. Ren R, Mayer BJ, Cicchetti P, Baltimore D 1993 Identification of a ten-amino acid proline-rich $\mathrm{SH} 3$ binding site. Science 259:1157-1161

7. Goujon L, Allevato G, Simonin G, Paquereau L, Le Cam A, Clark J, Nielsen JH, Djiane J, Postel-Vinay M-C, Edery M, Kelly PA 1994 Cytoplasmic sequences of the growth hormone receptor necessary for signal transduction. Proc Natl Acad Sci USA 91:957-961

8. Kishimoto T, Taga T, Akira S 1994 Cytokine signal transduction. Cell 76:253-262

9. Witthuhn BA, Quelle FW, Silvennoinen O, Yi T, Tang B, Miura O, Ihle JN 1993 JAK2 associates with the erythropoeitin receptor and is tyrosine phosphorylated and activated following stimulation with erythropoeitin. Cell 74: 227-236

10. Silvennoinen $O$, Witthuhn BA, Quelle F, Cleveland J, Yi T, Ihle JN 1993 Structure of the murine Jak2 protein-tyrosine kinase and its role in interleukin 3 signal transduction. Proc Natl Acad Sci USA 90:8429-8433

11. Johnston JA, Kawamura M, Kirken RA, Chen Y-Q, Bleke TB, Shibuya K, Ortaldo JR, McVicar DW, O'Shea JJ 1994 Phosphorylation and activation of the Jak-3 Janus kinase in response to interleukin-2. Nature 370:151-153

12. Witthuhn BA, Silvennoinen $O$, Miura $O$, Lai KS, Cwit $C$, Liu ET, Ihle JN 1994 Involvement of the Jak-3 Janus kinase in signaling by interleukins 2 and 4 in lymphoid and myeloid cells. Nature 370:153-157

13. Velazquez I, Fellous M, Stark GR, Pellegrini S 1992 A protein tyrosine kinase in the interferon $\alpha / \beta$ signalling pathway. Cell 70:312-322

14. Watling D, Gashin D, Muller M, Silvennoinen O, Witthuhn BA, Quelle FM, Rogers NC, Schindler C, Stark GR, Ihle JN, Kerr IM 1993 Complementation by the protein tyrosine kinase Jak-2 of a mutant cell line defective in the interferon- $\gamma$ signal transduction pathway. Nature 366: $168-170$

15. Hatakeyama M, Kono T, Tobayashi N, Kawahara A, Levin DS, Perlmutter RM, Taniguchi T 1991 Interaction of the IL-2 receptor with the Src-family kinase p56 lck: identification of a novel intermolecular association. Science 252:1523-1528

16. Miyajima A, Kitamura T, Harada N, Yokota T, Arai K 1992 Cytokine receptor and signal transduction. Annu Rev Immunol 10:295-331

17. Venkitaraman AR, Cowling RJ 1992 Interleukin 7 receptor functions by recruiting tyrosine kinase $\mathrm{p} 59^{\text {tyn }}$ through a segment of its cytoplasmic tail. Proc Natl Acad Sci USA 89:12083-12087

18. Ali S, Pellegrini I, Kelly PA 1991 A prolactin-dependent immune cell line (Nb2) expresses a mutant form of prolactin receptor. J Biol Chem 266:20110-20117 
19. Rui H, Kirken RA, Farrar WL 1994 Activation of receptorassociated tyrosine kinase JAK2 by prolactin. $\mathrm{J}$ Biol Chem 269:5364-5368

20. Lebrun JJ, Ali S, Sofer L, Kelly PA 1994 Prolactin induced proliferation of $\mathrm{Nb} 2$ cells involved tyrosine phosphorylation of the prolactin receptor and its associated tyrosine kinase JAK2. J Biol Chem 269:14021-14026

21. Clevenger CV, Medaglia MV 1994 The protein tyrosine kinase $p 59^{f y n}$ is associated with prolactin (PRL) receptor and is activated by Prl stimulation of T-lymphocytes. Mol Endocrinol 8:674-681

22. Clevenger CV, Torigoe T, Reed JC 1994 Prolactin induces rapid phosphorylation and activation of prolactin receptor-associated Raf-1 kinase in a T-cell line. J Biol Chem 269:5559-5565

23. Dusanter-Fourt I, Muller $O$, Ziemiecki $A$, Mayeux $P$, Drucker B, Djiane J, Wilks A, Harpur AG, Ficher S, Gisselbrecht S 1994 Identification of JAK protein tyrosine kinases as signaling molecules for prolactin. EMBO $\mathrm{J}$ 13:2583-2591

24. Lebrun JJ, Ali S, Ullich A, Kelly PA 1995 Proline-rich sequence-mediated Jak2 association to the prolactin receptor is required but not sufficient for signal transduction. J Biol Chem 270:10664-10670

25. Ihle JN, Witthuhn BA, Quelle FW, Yamamoto K, Thierfelder WE, Kreider B, Silvennoinen O 1994 Signalling by the cytokine receptor superfamily: JAKs and STATs. Trends Biochem Sci 19:222-227

26. Lesueur L, Edery M, Ali S, Paly J, Kelly PA 1991 Comparison of long and short forms of the prolactin receptor on prolactin-induced milk protein gene transcription. Proc Natl Acad Sci USA 88:824-828

27. O'Neal KD, Yu-Lee L 1994 Differential signal transduction of the short, $\mathrm{Nb2}$, and long prolactin receptors. J Biol Chem 269:26076-26082

28. Nagano N, Kelly PA 1994 Tissue distribution and regulation of rat prolactin receptor gene expression. $\mathrm{J}$ Biol Chem 269:13337-13345

29. Zabala MT, Garcia-Ruiz JP 1989 Regulation of expression of the messenger ribonucleic acid encoding the cytosolic form of phosphoenolpyruvate carboxykinase in liver and small intestine of lactating rats. Endocrinology 125:2587-2593

30. Villaiba M, Zabala MT, Martinez-Serrano A, Colina R, Satrústegui J, García-Ruiz JP 1991 Prolactin increases cytosolic free calcium concentration in hepatocytes of lactating rats. Endocrinology 129:2857-2861

31. Samelson LE, Phillips AF, Luong ET, Klausner RD 1990 Association of the fyn protein-tyrosine kinase with the T-cell antigen receptor. Proc Natl Acad Sci USA 87: $4358-4362$

32. Courtneidge SA, Dhand R, Pilat D, Twamley GM, Waterfield MR Boussel ME 1993 Artivation of Sre family ki- tion and characterization of $059^{\text {fyn }}$ (a src-like protein tyrosine kinase) in normal and polyoma virus transformed cells. EMBO J 7:3837-3844

38. Ryseck RP, Hirai SI, Yaniv M, Bravo R 1988 Transcriptional activation of c-jun during the G0/G1 transition in mouse fibroblasts. Nature 334:535-539

39. Müller R, Bravo R, Burckhardt J, Curran T 1984 Induction of C-fos gene and protein by growth factors preceedes activation of c-myc. Nature 312:716-720

40. Curran T, Franza BR 1988 Fos and Jun: the AP-1 connection. Cell 55:395-397

41. Minami $Y$, Taniguchi T 1995 IL-2 signaling: recruitment and activation of multiple protein tyrosine kinases by the components of the IL-2 receptor. Curr Opin Cell Biol $7: 156-162$

42. Erpel T, Courtneidge SA 1995 Src family protein tyrosine kinases and cellular signal transduction pathways. Curr Opin Cell Biol 7:176-182

43. Mori S, Rönnstrand L, Yokote K, Engström A, Courtneidge SA, Claesson-Weish L, Heldin C-H 1993 Identification of two juxtamembrane autophosphorylation sites in the PDGF $\beta$-receptor. Involvement in the interaction with Src family tyrosine kinases. EMBO J 12:2257-2264

44. Campbell GS, Argetsinger LS, Ihle NI, Kelly PA, Rillema JA, Carter-Su C 1994 Activation of Jak2 tyrosine kinase by prolactin receptors in Nb2 cells and mouse mammary gland explants. Proc Natl Acad Sci USA 91:5232-5236

45. Waters MJ, Daniel N, Bignon Ch, Djiane J 1995 The rabbit mammary gland prolactin receptor is phosphorylated in response to prolactin in vivo and in vitro. $\mathrm{J}$ Biol Chem 270:5136-5143

46. Lebrun J-J, Ali S, Goffin V, Ulirich A, Kelly PA 1995 A single phosphotyrosine residue of the prolactin receptor is responsible for activation of gene transcription. Proc Natl Acad Sci USA 92:4031-4035

47. Smith MR, DeGudicibus SJ, Stacey DW 1980 Requirement for c-ras proteins during viral oncogene transformation. Nature 320:540-543

48. Horvath AR, Muszbek L, Kellie S 1992 Translocation of $\mathrm{pp} 60^{\mathrm{c}-\mathrm{src}}$ to the cytoskeleton during platelet aggragation. EMBO J 11:855-861

49. Clark EA, Brugge JS 1993 Redistribution of activated pp60 $60^{\mathrm{c}-\mathrm{src}}$ to integrin-dependent cytoskeletal complexes in trombin-stimulated platelets. Mol Cell Biol 13:1863-1871

50. Armelin HA, Armelin MCS, Kelly K, Stwanley GM, Leder $\mathrm{P}$, Choran BH, Stiles CD 1984 Functional role for c-myc in mitogenic response to platelet-derived growth factor. Nature 310:655-660

51. Fumagalli S, Totty N, Hsuan JJ, Courtneidge SA 1994 A target for Src in mitosis. Nature 368:871-874

52. Shibuya $H$, Yoneyama M, Ninomiya-Tsujl J, Taniguchi T 1992 IL-2 and EGF receptors stimulate the hematopoi-

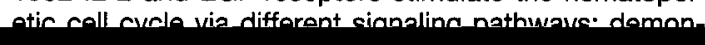

33. Kypta RM, Goldberg Y, Ulug ET, Courtneidge SA 1990 Association between the PDGF receptor and members of the Src family of tyrosine kinases. Cell 62:481-492

34. Bolen JB, Thompson PA, Eiseman E, Horak ID 1991 Expression and interactions of the Src family of tyrosine protein kinases in T lymphocytes. Adv Cancer Res 57: 103-149

35. Ralston R, Bishop JM 1985 The product of the protooncogene $\mathrm{c}$-src is modified during the cellular response to platelet-derived growth factor. Proc Natl Acad Sci USA 82:7845-7849

36. Gould KL, Hunter T 1988 Platelet-derived growth factor induces multi-sites phosphorylation of pp60 $0^{\mathrm{c}-\mathrm{src}}$ and increases its protein kinase activity. Mol Cell Biol 8:33453356

37. Kypta RM, Hemming A, Courtneidge SA 1988 Identifica-
Signal transduction by the high-affinity GM-CSF receptor: two distinct cytoplasmic regions of the common $\beta$ subunit responsible for different signalling. EMBO J 12: 4181-4189

54. Hems R, Ross BD, Berry MN, Krebs HA 1966 Gluconeogenesis in the perfused rat liver. Biochem $\mathrm{J}$ 101:284-291

55. Okamura H, Zachwieja J, Raguet S, Kelly PA 1989 Characterization and application of monoclonal antibodies to the prolactin receptor. Endocrinology 124:2499-2508

56. Aviv H, Leder P 1972 Purification of biologically active globin messenger RNA by chromatography on oligothymidilic acid-cellulose. Proc Natl Acad Sci USA 69:1408-1412

57. Yoo-Warren H, Cimbala MA, Kenneth F, Monahan JE, Leiss JP, Hanson RW 1981 Identification of a clone to phosphoenolpyruvate carboxykinase (GTP) from rat liver cytosol. J Biol Chem 256:10224-1022719 